\title{
Lymphocytic tumours of indeterminate nature: a 5-year follow-up of 98 conjunctival and orbital lesions
}

\author{
GWYN MORGAN AND JOHN HARRY \\ From the Department of Pathology, Institute of Ophthalmology, London
}

SUMmARY Ninety-eight adnexal lymphocytic tumours of indeterminate nature have been followed up for at least 5 years. Both non-disseminating and disseminating tumours have either very similar or identical histopathological features. It is not possible to make a definitive diagnosis when the lesions are first seen, and a conclusion can be reached only after a prolonged follow-up. The nature of the non-disseminating tumours is unknown.

Lymphomatous tumours of the ocular adnexa have been classified by previous authors into benign lymphoma, follicular lymphoma, lymphosarcoma, and lymphatic leukaemia. Apart from follicular lymphoma and lymphatic leukaemia, which in most cases can be diagnosed readily on histological and haematological grounds respectively, this classification presents some difficulties because the subsequent clinical course may belie the initial diagnosis made on biopsy. Thus, a tumour diagnosed 'benign' may later disseminate and conversely a 'malignant' tumour may not. In such instances either the original diagnosis was wrong or there is no sharp histological distinction to be made between benignity and malignancy.

It was Hochheim (1900), and Arnold and Becker (1872) who first recorded 'benign lymphomata' of the conjunctiva and orbit respectively. The tumours are uncommon, but may affect all ages and both sexes, may involve any part of the conjunctiva and orbit, and may be bilateral.

Conjunctival and orbital 'lymphosarcomata' were first reported by Vollaro (1899) and Silcock (1888). Such tumours are less common than 'benign lymphomata' (Duke-Elder, 1952).

\section{Materials and methods}

In order to examine the diagnostic difficulties of these tumours and to what extent the histological features can be correlated with the subsequent clinical course, Morgan $(1971,1975)$ carried out a

Address for reprints: Dr Gwyn Morgan, Department of Pathology, Institute of Ophthalmology, Judd Street, London WC1H 9QS long-term follow-up. It was found that there were no clinical differences between the non-disseminating and disseminating groups of tumours which could enable the ophthalmologist to make a definitive diagnosis. There were certain histopathological features, however, by which it was possible to differentiate the benign lymphomata from the lymphosarcomata. Germinal follicles (Fig. 1) and

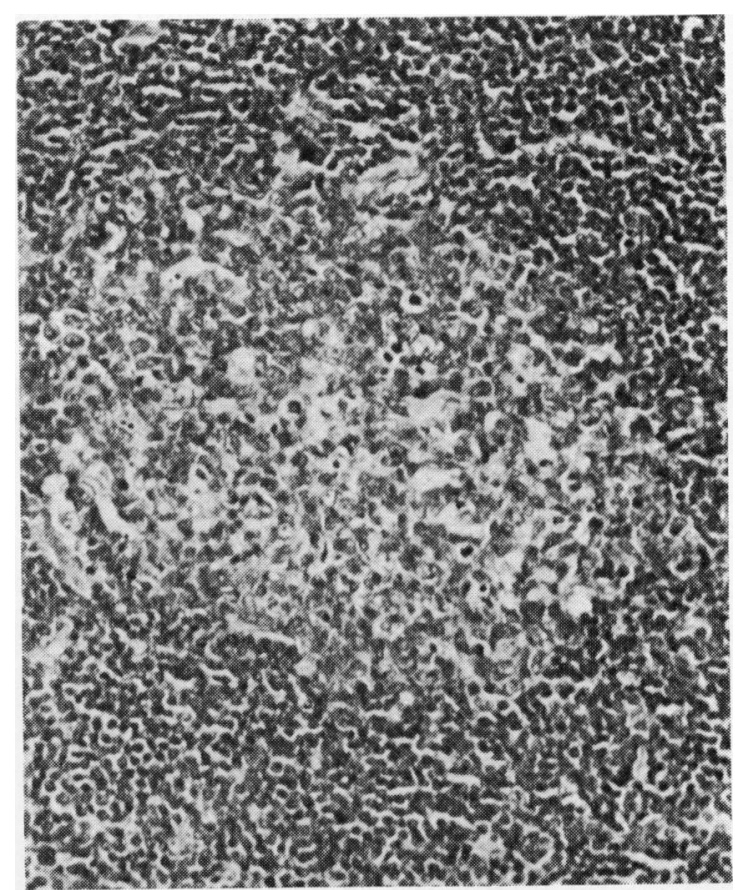

Fig. 1 A germinal follicle. $(H$ and $E \times 180)$ 


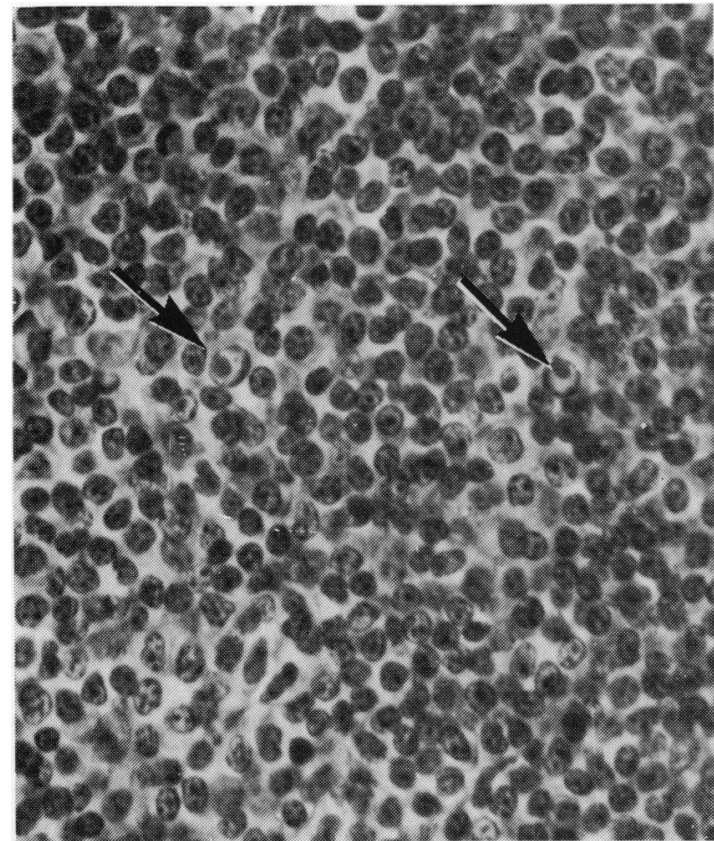

Fig. 2 Intranuclear inclusions (arrowed). (Periodic acid Schiff $\times 450)$

'intranuclear' inclusions (Dutcher bodies, Fig. 2) were found only in those tumours which did not disseminate, while lymphoblasts (Fig. 3) were found only in lymphosarcomata. The majority of lymphomatous tumours, however, had either identical or very similar features and were characterised by the presence of a sheet of lymphocytes with or without occasional other inflammatory cells such as plasma cells and reticulum cells. For the purpose of this study these tumours have been given the designation

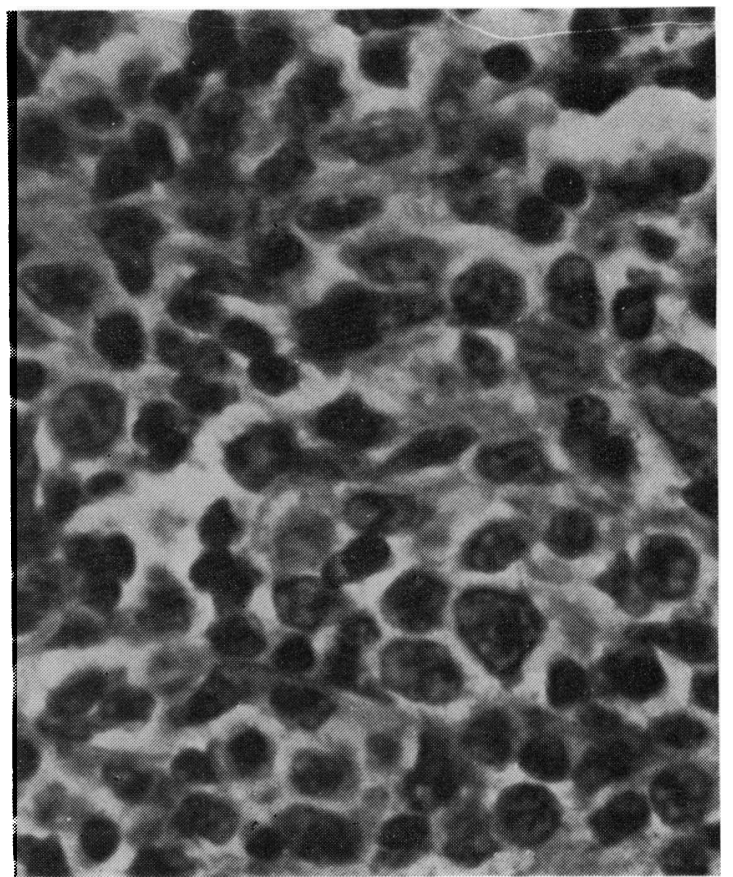

Fig. 3 Lymphoblasts. $(H$ and $E \times 720)$

'lymphocytic tumours of indeterminate nature' (Figs. 4 and 5). Ninety-eight such cases have been followed-up for at least 5 years.

\section{Results}

The results of the 5-year follow-up are summarised in Table 1. It is noted that local recurrences occurred in both the non-disseminating and disseminating groups of tumours. Seventy-four of the 98 cases

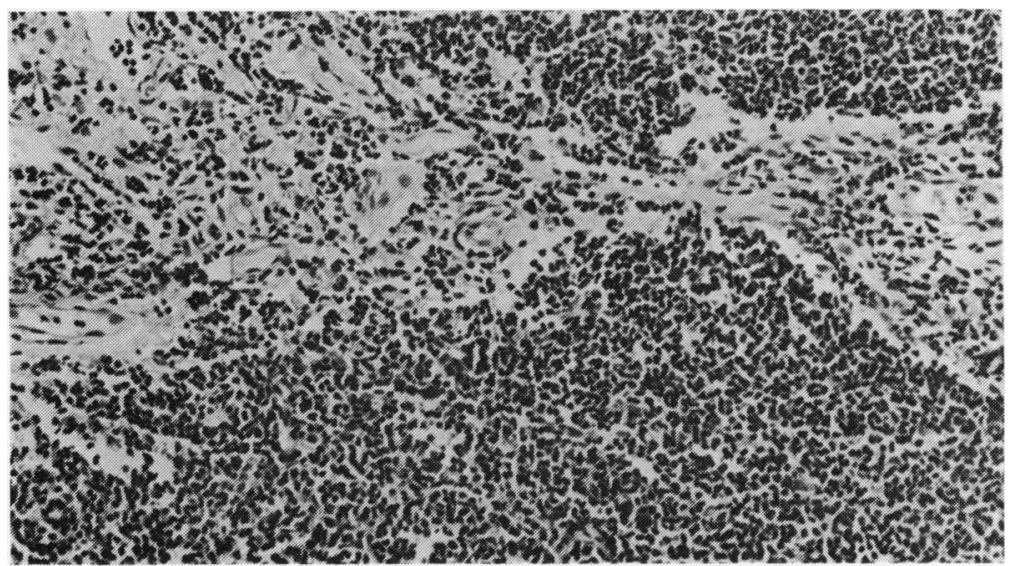

Fig. 4 Lymphocytic lesion of indeterminate nature $(H$ and $E$ $\times 145)$ 
Table 1 Five-year follow-up

\begin{tabular}{|c|c|c|c|c|c|}
\hline $\begin{array}{l}\text { Number of } \\
\text { cases }\end{array}$ & $\begin{array}{l}\text { Age } \\
\text { range }\end{array}$ & $\begin{array}{l}\text { Sex } \\
M / F\end{array}$ & Local recurrence & Non-disseminating tumours & Disseminating tumours \\
\hline 98 & $\begin{array}{l}17-84 \\
\text { years }\end{array}$ & $58 / 40$ & $\begin{array}{l}\text { Occurred in both non-disseminating } \\
\text { and disseminating tumours }\end{array}$ & $\begin{array}{l}74 \\
\text { Cases followed-up for } \\
\text { between } 5 \text { and } 39 \text { years }\end{array}$ & $\begin{array}{l}24 \\
\text { All patients died with widespread } \\
\text { lymphosarcoma or from other } \\
\text { causes between } 3 \text { and } 7 \text { years } \\
\text { after onset }\end{array}$ \\
\hline
\end{tabular}

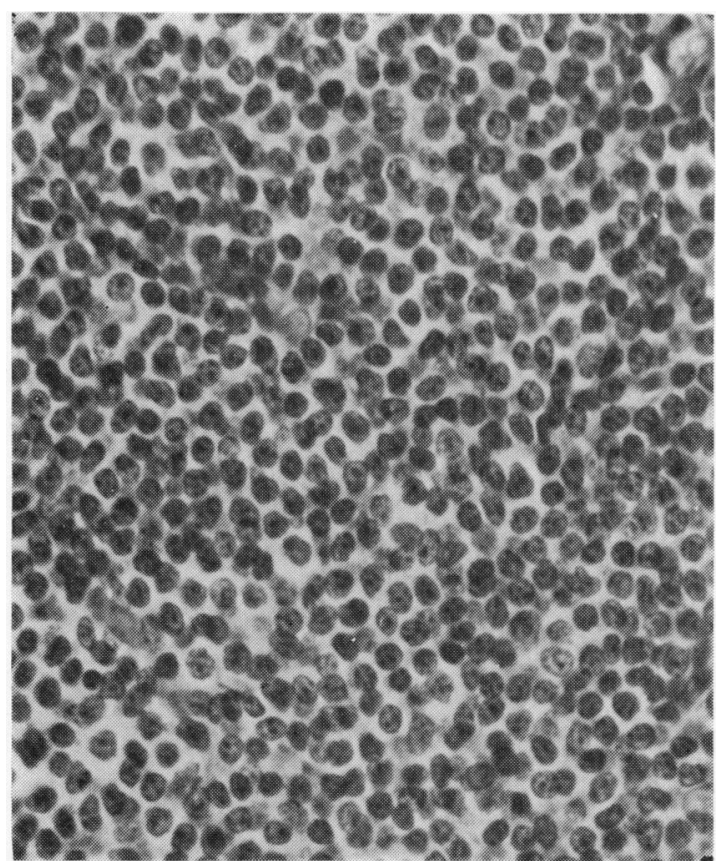

Fig. 5 Lymphocytic lesion of indeterminate nature showing scattered reticulum cells. $(H$ and $E \times 450)$

studied did not disseminate but 24 cases did, and 1 patient in this latter group died 7 years after the onset of the original ocular tumour.

\section{Discussion}

Ninety-eight lymphocytic tumours of indeterminate nature were followed up for a period of at least 5 years. The majority of the tumours (approximately $75 \%$ ) did not disseminate, but the remainder (approximately $25 \%$ ) developed generalised lymphosarcoma. It is of interest to report that a number of cases in the disseminating group had other evidence of lymphomatous disease when the conjunctival or orbital biopsy was first examined, but nevertheless, there were no distinguishing features in this material to enable a diagnosis of malignancy to be made on histopathological grounds. The fact that local recurrence occurred in both the non-disseminating and the disseminating tumour groups excluded this development as a sign of malignancy.

The nature of the non-disseminating tumours is unknown, and while they may represent lesions of lymphoid hyperplasia due to some aetiological agent we have been unable to demonstrate such a factor in any of our cases. Electron microscopical studies of selected cases have failed to identify any microorganisms, including viruses. The lesions are either very similar to or identical with those lymphocytic tumours which disseminate, so that they may represent neoplasms having a variable degree of malignant potential and possibly will eventually disseminate.

In the present state of our knowledge, therefore, we can only conclude that in cases of lymphomatous lesions which on histological grounds must be classified as indeterminate it is necessary to institute a prolonged follow-up to arrive at a definitive diagnosis.

We wish to thank Mrs Audrey Wood for providing secretarial help in the preparation of this paper.

\section{References}

Arnold, J., and Becker, O. (1872). Doppelseitiges symmetrisch gelegenes Lymphadenom der Orbita. Albrecht v. Graefes Archiv für Ophthalmologie, 18, 56-68.

Duke-Elder, S. (1952). Textbook of Ophthalmology, vol. 5, pp. 5551-5552. Kimpton: London.

Hochheim, W. (1900). Ein Beitrag zur Kentniss der symmetrischen Lid und Orbitaltumoren. Albrecht v. Graefes Archiv für Ophthalmologie, 51, 347-379.

Morgan, G. (1971). Lymphocytic tumours of the conjunctiva. Journal of Clinical Pathology, 24, 585-595.

Morgan, G. (1975). Lymphocytic tumours of the orbit. Modern Problems in Ophthalmology, 14, 355-360.

Silcock, A. Q. (1888). Round-celled sarcoma affecting both orbits. Transactions of the Ophthalmological Society of the United Kingdom, 8, 53-54.

Vollaro, A. L. (1899). Linfosarcoma della plica semilunare. Annali di Ottalmologia e Clinica Oculistica, 28, 58-68. 